\title{
Awareness of strategy execution barriers in decision-making process: moderated mediation analysis
}

\author{
Joanna Radomska ${ }^{(1)}$ - Cyprian Kozyra
}

Published online: 16 March 2020

(C) The Author(s) 2020

\begin{abstract}
Although many studies have discussed the strategy execution process and the reasons for its ineffectiveness, there is a need to consider the relations and interactions between the factors that hinder strategy implementation. The purpose of this article is to explore the interrelations between the strategy execution barriers by considering six factors and understanding the influence of these factors on a company's performance measured by its achievement of strategic goals (as one of the strategy execution measures) and its revenue dynamics (as a financial measure). In order to achieve the research goal, structural equation modelling was performed for the path analysis. The research sample, which consisted of 150 companies of different sizes and from different industries, was selected from the population of companies registered on the Warsaw Stock Exchange. The initial model of relationships was modified to create the final model from which insignificant paths had been removed. Our main finding is that the strategy implementation process should be perceived as a set of integrated factors, which should be analysed
\end{abstract}

J. Radomska ( $\square)$

Department of Strategic Management, Wroclaw

University of Economics, Wrocław, Poland

e-mail: joanna.radomska@ue.wroc.pl

C. Kozyra

Department of Statistics, Wroclaw University of

Economics, Wrocław, Poland

e-mail: cyprian.kozyra@ue.wroc.pl from an aggregated perspective in decision-making process. We believe that, rather than focusing only on the efficiency of final results, attention should be paid to ensure the effectiveness of all the factors aggregated in one construct and hence that it is necessary to regard the implementation process as an execution-as-learning concept. As revealed by our study, the awareness of strategy execution barriers directly impacts the achievement of strategic goals and indirectly impacts the revenue dynamics.

Keywords Strategy execution - Decision-making process $\cdot$ Strategy implementation barriers .

Awareness

\section{Introduction}

As reported by recent studies, executing strategy seems to be more important than the strategy itself (Balarezo and Nielsen 2017); at the same time, execution of strategy is more difficult than its formulation (El-Masri et al. 2015). This is mainly because execution is more complicated and time-consuming (Bell et al. 2010). Despite this, managers invest less time, energy and resources in the execution process (Bolboli and Reiche 2013). In the literature, we may observe a distinction between the scope of strategy execution and implementation. Such approach is 
based on the perspective presented by Favaro (2015), where strategy execution is aimed at turning implemented strategy into commercial success and is distinguished from strategy implementation, which consists of all the decisions and activities required to turn sets of strategic choices into reality. Therefore, strategy execution has more comprehensive and measurable perspective, which is also confirmed by Bossidy and Charan (2011). As the research in this article investigates the revenue dynamics and strategic goals achievement, the execution perspective was used.

The proportion of formulated strategies that were not executed or that were realized with poor results varies between 50 and $90 \%$, depending on the adopted research method (Sirkin et al. 2005). As Cândido and Santos (2015, p. 259) have suggested, "some of the evidence supporting these figures is outdated, fragmentary, lack scientific rigour or is just absent", which is an effect of the lack of a research protocol. The same incoherence is indicated by an analysis of the importance of the factors responsible for unsuccessful strategy execution. Many publications have focused on the gap between execution and strategy formulation caused by different factors affecting the failure of both stages (Stadler and Hinterhuber 2005), suggesting that the problem of strategy execution failure remains an important and ongoing issue.

Although the research results reveal many execution barriers (the factors that hinder strategy execution), most of them have a universal character and do not differ according to the type of organization analysed, as similar elements are indicated in companies as well as in public institutions (Al-Khouri 2014). Accordingly, many models, concepts and paradigms have been proposed. Most of them include the same set of convergent factors, sometimes differing in their names or scope. However, as suggested by Duarte and Austin (2016), more attention should be paid to the relations and interactions between the factors hindering strategy execution.

The aim of this article, therefore, is to explore the interrelations between the strategy execution barriers and to understand their influence on performance measured by strategic goals achievement (as one of the strategy execution measures, perceived by managers) and revenue dynamics (a financial measure). These two measures were adopted to ensure the validity of key informant data by using objective performance data as well as subjective assessment of performance, as recommended by Morgan et al. (2004). To achieve that goal, both a mediation analysis and a moderated mediation analysis were conducted using the structural equation modelling method.

\section{Theoretical background and hypotheses}

As reported by various studies, the strategy execution process integrates many intangible factors, including the top management support for actions initiated by lower-level employees (Ranganathan and Dhaliwal 2001), wide and two-way communication (Ariyachandra and Frolick 2008) and effective cooperation between organizational units (Bandara et al. 2005). These factors integrate the existing organizational system with the processes designed for strategy execution; however, such integration requires changes in resources distribution, task delegation and the organizational structure (Sikdar and Payyazhi 2014). These intangible aspects are also important because they shape the interactions between departments (Grover et al. 1999), organizational culture (Willcocks et al. 1997), climate and policy (Boonstra 2006). Therefore, perspectives on strategy execution are built from differentiated but combined elements that cannot be separated. For that reason, the available research results that are based on different research concepts are difficult to compare. Table 1 presents the research concepts that have been used to investigate the factors affecting the strategy execution process.

According to the first research perspective, the analysis should be based on the management functions whereby different problems may be identified. Although there would probably be differences according to the organization size, the listed factors present a coherent concept where various aspects of the organization are analysed. In the second approach, the listed elements are independent variables, and, although some intra-organizational relationships are considered, there are still no recommendations regarding the relations between them. In the case of hard-to measure factors, it is also important to consider the coordination and power delegation (Galbraith and Kazanjian 1986) or the interest groups and the conflicts involved (Reed and Buckley 1988). Therefore, the institutional context is emphasized (Jiang and Carpenter 2013). The third approach includes the 
Table 1 Different perspectives on factors affecting strategy execution, with sample references

\begin{tabular}{|c|c|c|c|c|c|c|c|}
\hline $\begin{array}{l}\text { Research } \\
\text { perspective }\end{array}$ & \multicolumn{2}{|c|}{ Management functions } & \multicolumn{3}{|c|}{ Hard-to-measure factors } & \multicolumn{2}{|c|}{ Measurable factors } \\
\hline Factors & \multicolumn{2}{|c|}{$\begin{array}{l}\text { Planning; organizing; } \\
\text { motivating, control }\end{array}$} & \multicolumn{3}{|c|}{$\begin{array}{l}\text { Organizational structure; organizational culture; } \\
\text { leadership; participation; communication; strategic } \\
\text { approach }\end{array}$} & \multicolumn{2}{|c|}{$\begin{array}{l}\text { Tools, systems, procedures, } \\
\text { processes, resources, } \\
\text { measurement }\end{array}$} \\
\hline Author & $\begin{array}{l}\text { Alashloo } \\
\text { et al. } \\
(2005)\end{array}$ & $\begin{array}{l}\text { Hrebiniak } \\
\text { (2005) }\end{array}$ & $\begin{array}{l}\text { Hrebiniak } \\
\quad(2005)\end{array}$ & $\begin{array}{l}7 \text { S (Waterman et al. } \\
\text { 1980; Eisenhardt and } \\
\text { Martin 2000; Ho } \\
\text { et al. 2013) }\end{array}$ & $\begin{array}{l}\text { 8S (Higgins } \\
\text { 2005; Mankins } \\
\text { and Steele } \\
\text { 2005) }\end{array}$ & $\begin{array}{l}\text { 8S (Higgins } \\
\text { 2005; Mankins } \\
\text { and Steele } \\
\text { 2005) }\end{array}$ & $\begin{array}{l}\text { BSC } \\
\text { (Kaplan } \\
\text { and Norton } \\
\text { 2001) }\end{array}$ \\
\hline
\end{tabular}

elements perceived as measurable and important for measuring the strategy execution progress and results achieved.

Although the set of key factors crucial for strategy execution has been identified in Table 1 their mutual interactions and connections have not been investigated thus (Kazmi 2008). Support for such a holistic approach was indicated by Beer and Nohria (2000), who recommended that a top-down approach (with emphasis on modifying structures and systems) should be integrated with a bottom-up approach (focusing on changes in communication and employee participation). It would be important to investigate the reciprocity and interdependence of top-down and bottom-up approaches, as they do not appear separately, but are usually a set of coexisting elements with a cumulative impact. This is the research gap we want to address. Such operational and comprehensive perspective is represented by EFQM concept (Fundamental Concepts of Excellence, 2013), where the six areas were determined-leadership, strategy, employees, resources, processes and measurement system. That concept is treated as an alternative for Balanced Scorecard where the measures are directly focused only on strategy execution measurement (Wongrassamee et al. 2003). Here, the factors that are investigated are of both financial (measurable) and nonfinancial (unmeasurable) nature. As it was designed to increase the effectiveness of decisionmaking process, we believe that it is worth investigating the structured perspective proposed as a set of key topics important for strategy execution (MartinCastilla and Rodriguez-Ruiz 2008). That is the perspective that we further develop. Based on the research results presented, we investigated six constructs that were chosen because they are the most commonly analysed and we combined within the measurable and hard-to-measure perspective. Our constructs were defined as a set of factors that are perceived as execution barriers in a particular area. A detailed definition is provided in Table 2. We have measured their importance (impact) for strategy execution.

Leadership

Leadership is the most often mentioned factor (Law and Ngai 2007), mainly because it determines the cohesion of visions with the actions undertaken (Hammer and Stanton 1995) and influences the level of knowledge about the importance of strategy execution process in the organization (HBR Spotlight 2010). Strategy formulation is the main task listed among the managerial responsibilities (Philipsen and Kemp 2003), which is influenced by the competitive development and personal goals that determine the understanding and use of strategy content (Postma and Zwart 2001). That impact on strategy content is manifested by core contribution to firms' value creation processes (Pugliese et al. 2009) but also defining and shaping the decisions and their exploration in particular contexts as pointed by McNulty and Pettigrew (1999).

This is enhanced especially by adopting a bottomup approach while formulating the strategy and supporting this process further with a clear communication strategy (Angel 2008). As a result, it is possible to find the bridge between strategy creators and implementers, which is reflected in the hierarchy of the organizational structure (Hamdi and Goethert 1985). However, the proper decision-making mechanism supporting the organizational learning process is required (Mezger and Violani 2011). According to Håkonsson et al. (2012), aspects such as management 
Table 2 Definitions of constructs. Source: based on Wongrassamee et al. (2003), Hrebiniak (2005), Eisenhardt and Martin (2000), Ho et al. (2013), Higgins (2005) and Mankins and Steele (2005)

\begin{tabular}{ll}
\hline Factor & Description \\
\hline Leadership & $\begin{array}{l}\text { Relates to the behaviour and competences of the executive team and other managers aimed at organizing the strategy } \\
\text { formulation and execution process }\end{array}$ \\
$\begin{array}{l}\text { Employees } \\
\text { Relates to the potential and skills useful for improving the strategy execution process }\end{array}$ \\
$\begin{array}{l}\text { Relates to the way how organization designs, manages and improves the processes crucial for effective strategy } \\
\text { execution }\end{array}$ \\
$\begin{array}{l}\text { Resources } \\
\text { Relates to the process of examining the results achieved in relation to the planned execution performance } \\
\text { performance } \\
\text { content }\end{array}$ & $\begin{array}{c}\text { Relates to the values, vision and strategic decisions and their internal coherence, flexibility and easiness to be } \\
\text { transformed into detailed objectives }\end{array}$ \\
\hline
\end{tabular}

style and the ability to process and analyse the information have an important impact in this case.

On the other hand, the role of leaders includes not only extensive cooperation, but also the evaluation of emerging opportunities to build a competitive advantage and make the right decisions aimed at executing development concepts (Forbes and Milliken 1999). To achieve this, leaders need to adopt a proactive attitude and ensure that they are involved in execution activities (Hanley 2007), and they should also possess the knowledge and information necessary to make effective strategic decisions (Carpenter and Westphal 2010). This requires having a diverse set of skills and abilities (Miller et al. 2008), especially those that support a wide-ranging dialogue aimed at establishing the details of the executed strategy and those that maintain the consistency of the activities carried out (Getz and Lee 2011). One recommendation for increasing the effectiveness of the strategy execution process is to improve the ability to prioritize, which means choosing those initiatives that seem to be the most promising for the organization's development. However, it is important to understand the implications of these initiatives, such as the appropriate allocation of resources (Legge 2014). It also requires being consistent, as the success of a given strategic initiative is rarely the result of a single action. Rather, it is a process that evolves over time and consists of repetitive sequences of events (Garvin 2013).

Many recommendations concern the desired leadership features. However, there are relatively few studies that analyse factors such as education, previous experience (Zhang and Rajagopalan 2010) or personality (Chin et al. 2013), all of which strongly influence strategic behaviour (Peterson et al. 2009), the strategic choices made and the strategy itself (Chatterjee and Hambrick 2007). Moreover, the manager's personality can strengthen or hinder closer relations with other employees (Herrmann and Nadkarni 2014) and thus affect the climate and work environment by shaping processes, structures or incentive systems (Resick et al. 2009). The gender of the manager should also be considered (Alpha and Sabourin 2012), especially in the risk-taking approach (Gorzeń-Mitka 2015). As emphasized by Prahalad and Bettis (1987), the manager's personal characteristics, regardless of the position in the organizational hierarchy, always influence the cognitive perspective.

While analysing the leadership factor, it is also important to consider the organizational process by focusing on the relationships between the board, managers and mid-level managers, which could be a source of conflicts and tensions in their mutual relations (Kipp and Kipp 2012). The involvement of mid-level managers has already been investigated (Alamsjah 2011), and research results have proved their importance in the strategy execution process that mainly stems from their ability to ensure a combination of operational and strategic issues (Burgelman 1983), but also from their positive impact on the results achieved (Wooldridge and Floyd 1990) and their greater knowledge about the strategy (Collier et al. 2004). However, mid-level managers are strongly driven by their personal interests, so social/ 
emotional factors should also be considered (Huy 2011). Based on the arguments presented, we may conclude that leadership is the factor that influences all organizational aspects and, therefore, that it may have either supplementary or compensatory effects (O'Reilly et al. 2010). Given these considerations, it is hypothesized that:

$\mathbf{H}_{1 \mathbf{a}}$ Leadership has a positive impact on the strategy content.

$\mathbf{H}_{\mathbf{1 b}}$ Leadership has a positive impact on the employees in strategy execution.

$\mathbf{H}_{1 \mathbf{c}}$ Leadership has a positive impact on the resources in strategy execution.

$\mathbf{H}_{1 d}$ Leadership has a positive impact on the processes in strategy execution.

$\mathbf{H}_{1 \mathbf{e}}$ Leadership has a positive impact on the measures of strategy execution.

All hypotheses in this paper should be interpreted in accordance with the operational definition of constructs. For example, $\mathrm{H}_{1 \mathrm{a}}$ means "the higher the importance of strategy execution barriers in the leadership area, the higher the importance of strategy execution barriers in strategy content".

\section{Employees}

According to Raps (2005), broadening the responsibility for strategy execution should not be limited only to mid-level managers, but should also include a wider group of employees, as we may identify a link between the level of conscious involvement in strategic initiatives and the higher efficiency of strategy execution (Renckly 2004; Saif et al. 2013; Wart 2010). This involvement considers not only the participation in decision-making processes or strategy formulation, but also the stage of strategy communication and transposition into operational practices (Salas and Huxley 2014). However, this requires employees to have appropriate skills (Huselid and Becker 2011). Therefore, it is recommended to include specific training as part of an organizational performance improvement system (Sørensen and Holman 2014). Such skills are a key element in increasing the efficiency of operating goals (Paillé et al. 2014) and one of the nonfinancial components of the incentive system (Khadem 2008) related to the strategy execution results (Aksakal and Dagdeviren 2014). As concluded by Maditinos et al. (2014), there is a link between the skills and competences increased by special training and a higher probability of executing the strategy successfully. Sue and Khawaja (2015) further found that those capabilities are necessary at all managerial levels and in all managerial processes. Therefore, $\mathrm{H}_{2}$ was hypothesized:

$\mathbf{H}_{2}$ Employees have a positive impact on the processes in strategy execution.

\section{Processes}

As mentioned by Yaprak et al. (2011), effective strategy execution requires ensuring the internal match between the strategy itself and the organizational structure and performed processes. Moreover, as outlined by Hanafizadeh and Moayer (2008), defining the strategic processes helps organizations to use their resources based on their objectives. There are several processes that are important for ensuring the proper strategy execution. The one that is mentioned most frequently is the process of communication (Foreman and Argenti 2005), which is aimed at eliminating the barriers between people responsible for executing changes and those who directly face their effects (Terziovski et al. 2003). However, effective execution includes more complex activities than explaining and communicating the strategy in the organization (Lepsinger 2006). According to Driedonks et al. (2014), the effectiveness of the communication process is influenced by its reciprocal character, understood as a combination of bottom-up and top-down approaches. Moreover, it is recommended to consider the mutual impact of horizontal and vertical information flow, which is often based on interpersonal relationships (Thanyawatpornkul et al. 2016). Therefore, it is postulated that a combination of methods, integrating oral, written and visual presentations, should be used (Conrad 1990). However, as observed by Guetzkow (1965), we may identify the communication paradox whereby the employees who receive extensive information from their superiors are the group most often declaring an insufficient level of information. This is confirmed by research results, according to which over $90 \%$ of middle-level managers report sufficient frequency of strategy communication, whereas only $55 \%$ of them are able to name 
one of the strategic priorities of the organization (Sull et al. 2015). Thus, effectiveness of the communication process is highly important.

The process of effective feedback and control is also mentioned in the literature (Okumus 2003), which especially highlights the need to consider not only the direct supervision (Bolboli and Reiche 2013), but also the comprehensiveness of the monitoring system, the regularity of control and the relevance of the measures used (Shah and Sid Nair 2014). To ensure this comprehensiveness, a good information system should be developed first in order to guarantee the unlimited access and update possibility for all employees involved in the execution process (Obeidat et al. 2017).

Another issue investigated by some researchers is the coherence between the organizational structure and strategy execution (Robbin and DeCenzo 2005). For such coherence, the relations between tasks, their delegation and the formal and informal information channels are important (Olsen et al. 1992). Unclear links, division of responsibilities or decision-making process is often caused by an inadequate organizational scheme in which many managers are unable to coordinate the tasks assigned (Heide et al. 2002). Therefore, as found by Brenes et al. (2008), designing an organizational structure according to strategic priorities is one of the key factors affecting the effectiveness of the strategy execution process. For that reason, as reported by Rajasekar (2014), in most of the surveyed enterprises the significant modifications to the organizational structure are executed in an attempt to ensure the structure's consistency with the strategy and strategic goals. Most managers perceive such adaptations as a requirement for ensuring their effectiveness (Olson et al. 2005). However, due to the considerable variation among organizational structures, there is no direct recommendation regarding the organizational structure's design that will ensure a higher degree of effectiveness of operational activities. The priority should be given to diagnosing the degree of the adjustment between the organizational structure and the executed strategy (Miller et al. 2004); based on that analysis, further modifications of processes could be introduced (Pleshko and Nickerson 2008). However, as postulated by Vermuelen et al. (2010), slight changes should be considered in periods both of incremental changes and of relative stability. As recommended by Kohlbacher (2010), it is necessary to ensure the integration of strategy, organizational structure and coordination of resources in one process, which is reflected in following hypotheses:

$\mathbf{H}_{3}$ Processes in strategy execution are positively impacted by strategy content as well as resources.

$\mathbf{H}_{6}$ There is a positive impact of processes in strategy execution on strategic goals achievement.

\section{Measures}

The main role of a measurement system is to indicate the degree of strategic goals achievement and to report any execution problems that occur (Markiewicz 2012). The research results show the relation between the usage of execution tools, the improvement of the effectiveness of a strategy execution measurement system and the reduction of employees' resistance to the changes introduced. Therefore, it is recommended to adopt a comprehensive approach that encompasses the relations between the tools, the measures and the measurement system (Radomska 2016).

It is also worth noting that there are financial and non-financial perspectives on strategy execution measurement, and each of these different approaches has advantages and disadvantages. However, Miller (1997) and Okumus (2003) argue that completion, achievement and acceptability of final results are among the three criteria that should be considered; based on these arguments, we may further analyse the degree of strategic goals achievement as one of the measures of strategy execution effectiveness. Therefore, another area worth investigating concerns the link between the execution tools and the measurement of strategy execution progress, especially as there are relatively few models that describe the links between the strategy and its measures (Malmi 2001).

$\mathbf{H}_{4}$ The importance of strategy content has a positive impact on the importance of measures for strategy execution.

$\mathbf{H}_{5}$ Processes in strategy execution have a positive impact on the strategy execution measures.

$\mathbf{H}_{7}$ There is a positive impact of strategy execution measures on strategic goals achievement. 
Resources

As mentioned by Nag et al. (2007), neither formulation nor execution of the strategy should be done without considering the resources possessed. The importance of resources availability has been confirmed by many studies. They are the key factor necessary for the execution of each development option, regardless of its expansiveness and character (Lingle and Schiemann 1994). Financial resources are considered to be the most important (Sterling 2003), mainly because of their impact on the quantity and quality of other resources (Anand and Merrifield 1982). Therefore, strategic discipline is required, which results in high consistency during the process of selecting strategic initiatives and avoids the reallocation of resources due to emerging opportunities, since such reallocation may not be coherent with the main strategy and may negatively influence the speed of necessary changes (Kaplan and Norton 2001). However, as Sull et al. (2015) have indicated, the vast majority of managers prefer flexibility over organizational cohesion, which may lead to significant limitations in the strategy execution process. Moreover, as mentioned by Bower (1986), there is a risk associated with delegating decisions about resource allocation, because these decisions impact on the design of final processes and may lead to differences between the intended and executed strategy.

Strategy and performance

As outlined by Barnett and Carroll (1995), the process of introducing change is as important as the content of that change. This was further confirmed by Beer and Eisenstat (2000), who identified unclear strategy and conflicting priorities as critical factors for strategy execution. The concept of development is crucial, because it is relevant to other factors supporting the execution process and impacts on their content (Hrebiniak 2013). This has been confirmed by Brenes et al. (2008), who found that explicit strategy (clear and written) is essential for a successful execution process. As mentioned by Martin (2010), in some cases the strategy itself is the reason for low profitability, even when its execution was efficient, mainly because the line between strategy formulation and execution has not been sharp. However, as recommended by Mintzberg (2002), executives must clearly understand the strategic direction and, therefore, the main goals, priorities and actions that are required. As defined by Lee and Puranam (2016, p. 1529), the precision of strategy execution is "the extent to which an organization's actions correspond to its strategic intentions". To keep that correspondence, the strategy has to be measurable. Some recommendations consider financial indicators such as the rate of return on assets, net profit or return on investment (Bakar and Ahmad 2010), while others consider non-financial measures (Ittner and Larcker 2003). However, as mentioned by Serra and Kunc (2015), strategy execution can also be measured by the degree of strategic goals accomplishment, as these goals reveal the gap between the current and desired states, and they are used as one of the performance measures. As reported by Siam and Hilman (2014), we may observe the correlation between the degree of strategic goals achievement and the profitability of the actions taken (reflected in the revenue dynamics), which is why the strategic goals are considered as one of the organizational performance measures (Chaola et al. 2015). For that reason, we wanted to verify whether:

H8 The higher the strategic goals achievement, the higher the revenue dynamics.

Therefore, strategic goals achievement is a mediating variable between the factors described above and revenue dynamics as a final predicted variable in the model. In order to achieve the research goal, we created an initial structural model, with direct and indirect relationships reflecting the hypotheses. Figure 1 presents the conceptual path model.

The factors represent either measurable or hard-tomeasure elements of a comprehensive strategy execution approach. The research gap that we identify includes the relations between these factors as well as their influence on strategic goals achievement and revenue dynamics.

\section{Research design}

Sample and data collection

The research sample contained 150 firms listed on the Warsaw Stock Exchange main market and on the alternative New Connect market. The entities differed 


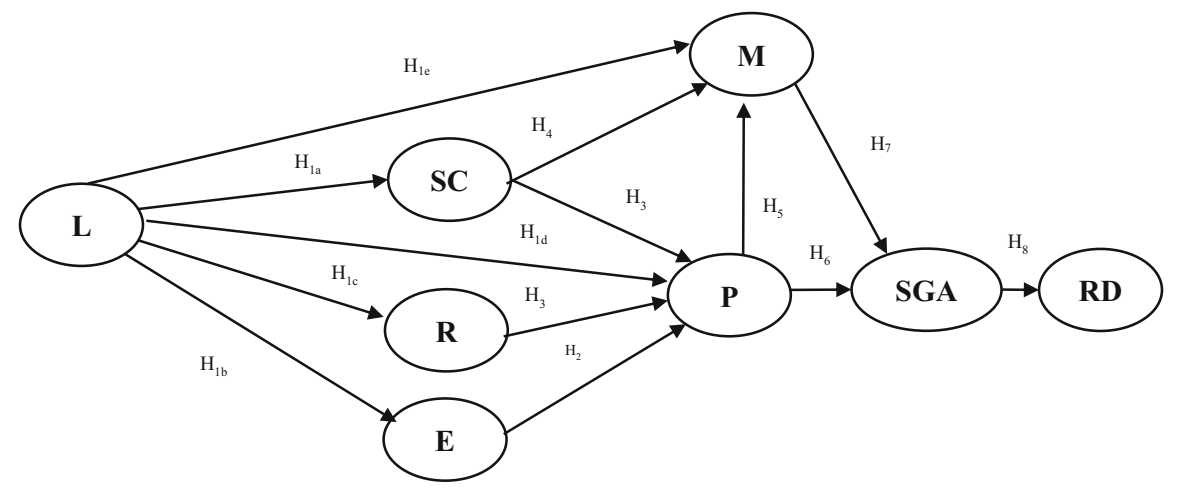

Fig. 1 Conceptual path model. L-the importance of leadership for strategy execution, SC-the importance of strategy content for strategy execution, E-the importance of employees for strategy execution, $\mathrm{R}$ - the importance of resources for

in size and industry sector. This differentiated sample enabled us to investigate whether the relations between constructs are moderated by those characteristics. The stock exchange requires transparent and standard reporting. The respondents (CEOs, owners, strategy managers and board members) were responsible for strategy formulation and execution. A stratified random method was used to select the sample according to industry sector (defined according to the classification introduced at Warsaw Stock Exchange) and the company's size.

The study was conducted in 2017 with a direct questionnaire interview, and the survey was carried out by using the paper-and-pencil interviewing method. The main part of the survey investigated the importance of given factors for the strategy execution process. A five-point Likert-type scale was used to measure importance: (1) very low (5\%); (2) low (25\%); (3) medium (50\%); (4) high (75\%); and (5) very high (more than 90\%). The data collection enabled the perception of respondents to be studied, which could be considered a limitation of the study. These latent variables represent qualities that are not directly measured (Tabachnick and Fidell 2001) and the constructs according to the subjective perspective of individuals (Borsboom et al. 2003). Revenue dynamics as a final predictive variable was measured objectively based on the data from financial reports.

According to the literature review presented, yet no scale has been developed that could sufficiently fit the research topic. Therefore, a new measurement scale was developed. Based on the EFQM concept strategy execution, $\mathrm{P}$ - the importance of processes for strategy execution, $\mathrm{M}$ - the importance of measures for strategy execution, SGA—strategic goals achievement, RD—revenue dynamics

(Fundamental Concepts of Excellence 2013), six areas of operational (intra-organizational) risk were identified-leadership, strategy, employees, resources, processes and measures. Within those areas, the scale items were formulated based on the perspectives derived from the literature review and qualitative interviews with ten experts (CEOs responsible for strategy execution). The list of scale items is presented in "Appendix". The scale validation included the content validity (EFQM concept) (Diamantopoulos and Siguaw 2006), facade validity (expert judges) (Hardesty and Bearden 2004) and nomological validity (Suddaby 2010). Measurement reliability analysis was performed using Cronbach's alpha coefficient. Path analysis was selected as a method for verifying the set of research hypotheses, which produce conceptual direct and indirect causal relationships between constructs (leadership is the only exogenous variable and a root in the causal model). The path analysis was performed using the structural equation modelling module SEPATH in the Statistica (ver. 12) software.

\section{Results}

The hypotheses were tested using SEM. Our results support some of the hypotheses and suggest that our conception of direct and indirect relations should be revised. Table 3 presents the correlation matrix and Cronbach's alpha. 
Table 3 Correlation matrix between variables and construct measurement reliability (Cronbach's alpha on diagonal)

\begin{tabular}{|c|c|c|c|c|c|c|c|c|}
\hline Variable & IL & IS & IE & IR & IP & IM & SGA & $\mathrm{RD}$ \\
\hline $\mathrm{L}$ & 0.861 & $0.814 *$ & $0.810^{*}$ & $0.792 *$ & $0.877^{*}$ & $0.836^{*}$ & $0.255^{*}$ & 0.106 \\
\hline $\mathrm{SC}$ & & 0.842 & $0.822 *$ & $0.881 *$ & $0.906^{*}$ & $0.813^{*}$ & $0.292 *$ & 0.019 \\
\hline $\mathrm{E}$ & & & 0.822 & $0.835^{*}$ & $0.877^{*}$ & $0.819 *$ & $0.315^{*}$ & 0.102 \\
\hline $\mathrm{R}$ & & & & 0.804 & $0.865^{*}$ & $0.802 *$ & $0.237 *$ & 0.091 \\
\hline $\mathrm{P}$ & & & & & 0.813 & $0.908^{*}$ & $0.283 *$ & 0.095 \\
\hline M & & & & & & 0.773 & $0.323^{*}$ & 0.078 \\
\hline SGA & & & & & & & - & $0.158 * *$ \\
\hline RD & & & & & & & & - \\
\hline
\end{tabular}

As presented in Table 2, all multi-item constructs are reliably measured with the scales proposed. Moreover, high and significant correlations between constructs can be observed. Revenue dynamics is significantly correlated only with strategic goals achievement.

\section{Mediation analysis}

Path analysis examining the mediation model based on the presented correlation matrix was performed according to the conceptual research framework. We evaluated model fit by means of the Chi-squared statistic, goodness-of-fit index (GFI), Bentler comparative fit index (CFI), the Bentler-Bonett normed fit index (NFI) and the standardized root-mean-square residual (RMR). The detailed research results are presented in Table 4.

The research results indicate that not all conceptual relations have been confirmed. $\mathrm{H}_{1}$ predicted that leadership is positively related to other constructs, and this hypothesis is supported. $\mathrm{H}_{2}$ predicted that the importance of employees is crucial for processes in strategy execution (0.264), and it is supported. $\mathrm{H}_{3}$ was based on the assumption that processes involved in strategy execution are positively impacted by strategy content as well as resources, and this is confirmed by the research results. $\mathrm{H}_{4}$ predicted that strategy content has a positive impact on the measures of strategy execution, but the results were not significant ( $p=0.317$ ); thus, this hypothesis is not supported by the data. $\mathrm{H}_{5}$ assumed that the strategy execution processes have a positive impact on the measures of strategy execution; the results present a high value of the parameter $(0.807)$, so this hypothesis is confirmed. However, the research results do not confirm the impact of the processes on strategic goals achievement $\left(\mathrm{H}_{6}\right)$. In the case of $\mathrm{H}_{7}$, the positive impact of measures on strategic goals achievement is considered significant, so the hypothesis is supported. Finally, $\mathrm{H}_{8}$
Table 4 Initial model estimates

\footnotetext{
Model fit: ${ }^{2}(15)=156.7$, $p<0.001 ; \mathrm{CFI}=0.882$; $\mathrm{GFI}=0.793$; NFI $=0.872$; $\mathrm{RMR}=0.075$
}

\begin{tabular}{lclrc}
\hline & Parameters estimate & Standard error & $T$ statistic & $p$ value \\
\hline$[\mathrm{L}]->[\mathrm{SC}]$ & 0.814 & 0.028 & 29.007 & 0.000 \\
{$[\mathrm{~L}]->[\mathrm{IE}]$} & 0.810 & 0.029 & 28.343 & 0.000 \\
{$[\mathrm{~L}]->[\mathrm{R}]$} & 0.792 & 0.031 & 25.518 & 0.000 \\
{$[\mathrm{~L}]->[\mathrm{P}]$} & 0.300 & 0.069 & 4.360 & 0.000 \\
{$[\mathrm{~L}]->[\mathrm{M}]$} & 0.178 & 0.081 & 2.210 & 0.027 \\
{$[\mathrm{SC}]->[\mathrm{P}]$} & 0.400 & 0.047 & 8.558 & 0.000 \\
{$[\mathrm{SC}]->[\mathrm{M}]$} & -0.071 & 0.070 & -1.001 & 0.317 \\
{$[\mathrm{E}]->[\mathrm{P}]$} & 0.264 & 0.047 & 5.668 & 0.000 \\
{$[\mathrm{R}]->[\mathrm{P}]$} & 0.079 & 0.044 & 1.781 & 0.075 \\
{$[\mathrm{P}]->[\mathrm{SGA}]$} & -0.055 & 0.186 & -0.296 & 0.767 \\
{$[\mathrm{P}]->[\mathrm{M}]$} & 0.807 & 0.091 & 8.869 & 0.000 \\
{$[\mathrm{M}]>[\mathrm{SGA}]$} & 0.369 & 0.184 & 2.009 & 0.045 \\
{$[\mathrm{SGA}]->[\mathrm{RD}]$} & 0.158 & 0.081 & 1.946 & 0.052 \\
\hline
\end{tabular}


assumed that the higher the strategic goals achievement, the higher the revenue dynamics; this hypothesis is supported, although the relationship is weak (0.158).

Based on these results, the final structural model was modified (Fig. 2). Insignificant relationships $(p>0.1)$ were removed from the initial model $([\mathrm{SC}]->[\mathrm{M}]$ and $[\mathrm{P}]->[\mathrm{SGA}])$.

To improve the model fit $\left({ }^{2}(15)=156.7\right.$, $p<0.001 ; \mathrm{CFI}=0.882$; GFI $=0.793 ; \mathrm{NFI}=0.872$; RMR =0.075), we respecified the model to explore whether the exclusion of insignificant relationships would influence the other relations. The results of this respecification are presented in Table 5 and in Fig. 2.

The fit of both the conceptual and the final models is comparable $\left(\Delta^{2}(2)=0.836 ; p=0.658\right)$, so removing the insignificant paths between constructs from the initial model leads to a more parsimonious model describing the relationships between variables. Nevertheless, the final model still did not reveal the perfect fit indexes. The reason for this lack of fit could be insufficient divergent measurement validity of constructs, since the correlations between them reported in Table 2 are too high. Therefore, we introduced the aggregated model, where all the items are represented as a general awareness of strategy execution barriers. That awareness is defined as comprehensive barrier perception, which is different than the concept of strategic awareness introduced by Hambrick (1981). Cronbach's alpha for this aggregated construct is equal to 0.967 , which allows to conclude that to measure that construct in the joined areas described, a shorter version of questionnaire could be used. The detailed relations in this framework are presented in Fig. 3. The direct impact of awareness on revenue dynamics was also verified.

The model has no degrees of freedom to test the goodness of fit, and we can observe in Table 6 that one of the relations was not confirmed ([AW] $->$ [RD]; $p=0.611$ ), so it was removed.

The final aggregated model estimates are presented in Table 7. The model fit indexes confirm that the model fits the data well $\left(^{2}(1)=0.258, p=0.612\right.$; $\mathrm{CFI}=1 ; \mathrm{GFI}=0.999 ; \mathrm{NFI}=0.986 ; \mathrm{RMR}=0.016$ ).

Based on these research results, we may affirm that the aggregation of constructs was justified.

Moderated mediation analysis

Furthermore, a moderated mediation analysis was conducted by means of comparing the fit of two nested multigroup path models: the first model with all parameters assumed to be equal in all groups, and the second model with all parameters free to be estimated in every group. The difference of the Chi-squared statistics of the two nested models reveals a Chisquared distribution with the number of degrees of freedom equal to the difference of degrees of freedom in two models. The main aim of the moderation analysis was to check whether the moderators, such as industry or the size of the company, affect the relationships that were identified in the model. We chose these moderators (size and industry) because they were used in the sample selection.

Our research revealed that there is no moderation in the case of company size. Initially, we estimated the model with separated constructs in three groups depending on the number of employees (about onethird of the whole sample in each group). All parameters can be considered similar regardless of the size of the company, which was also confirmed by the difference of Chi-square fit statistics $\left(\Delta^{2}(22)=25.781 ; p=0.261\right)$.

However, moderation can be identified in the case of the industrial sector in which the company operates.

Fig. 2 Final structural model. $* p<0.05$, ** $0.05<p<0.1$

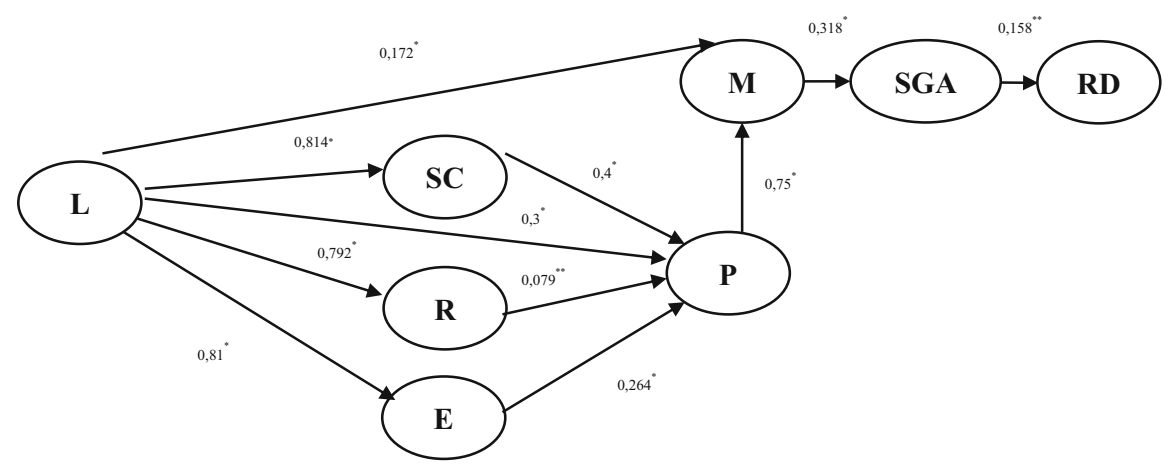


Table 5 Final model estimates

\begin{tabular}{lllcc}
\hline & Parameters estimate & Standard error & $T$ statistic & $p$ value \\
\hline$[\mathrm{L}]->[\mathrm{SC}]$ & 0.814 & 0.028 & 29.007 & 0.000 \\
{$[\mathrm{~L}]->[\mathrm{E}]$} & 0.810 & 0.029 & 28.343 & 0.000 \\
{$[\mathrm{~L}]->[\mathrm{R}]$} & 0.792 & 0.031 & 25.518 & 0.000 \\
{$[\mathrm{~L}]->[\mathrm{P}]$} & 0.300 & 0.069 & 4.361 & 0.000 \\
{$[\mathrm{~L}]->[\mathrm{M}]$} & 0.172 & 0.080 & 2.151 & 0.031 \\
{$[\mathrm{SC}]->[\mathrm{P}]$} & 0.400 & 0.047 & 8.557 & 0.000 \\
{$[\mathrm{E}]->[\mathrm{P}]$} & 0.264 & 0.047 & 5.668 & 0.000 \\
{$[\mathrm{R}]->[\mathrm{P}]$} & 0.079 & 0.044 & 1.782 & 0.075 \\
{$[\mathrm{P}]->[\mathrm{M}]$} & 0.750 & 0.076 & 9.865 & 0.000 \\
{$[\mathrm{M}]>[\mathrm{SGA}]$} & 0.318 & 0.075 & 4.266 & 0.000 \\
{$[\mathrm{SGA}]->[\mathrm{RD}]$} & 0.158 & 0.081 & 1.945 & 0.052 \\
\hline
\end{tabular}

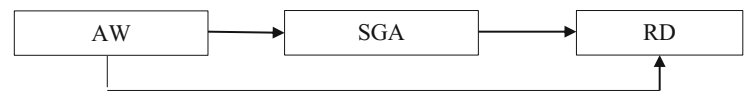

Fig. 3 Aggregated research model. AW-awareness of strategy execution barriers (comprehensive barrier perception including all factors: leadership, strategy, employees, resources, processes and measures factors), SGA — strategic goals achievement, RD—revenue dynamics

The model estimated for three types of industries revealed different parameters, which are presented in Tables 7, 8 and $9\left(\Delta^{2}(22)=52.870 ; \mathrm{p}<0.001\right)$. The industries were grouped and classified according to the Warsaw Stock Exchange classification: manufacturing and construction $(n=48)$; trade and financial services $(n=53)$; and other services $(n=49)$. The results for the estimates of the three models in separated subsamples are presented in Tables 8,9 and 10 .
In the case of other services, some relations- $[\mathrm{L}]$ $>[\mathrm{P}](p=0.113)$ and $[\mathrm{E}]->[\mathrm{P}](p=0.121)$ —could be removed, which means that we could not identify any relation between the processes and leadership or employees (their importance for strategy execution). Moreover, there is no relation between SGA and RD, which was also revealed in the case of manufacturing and construction. We were also able to identify a negative relation in that industry sector, namely [IL] $>[\mathrm{M}](p=-0.250)$. Another negative relationship was identified in the case of trade and financial services: $[\mathrm{R}]->[\mathrm{P}](p=-0.213)$. However, the fit indexes were not perfect.

Finally, we investigated the final aggregated model in order to reveal the moderation of size or industry; however, this was not confirmed (size: $\Delta^{2}(4)=1.17$; $p=0.883$; industry: $\left.\Delta^{2}(4)=0.908 ; p=0.923\right)$.
Table 6 Aggregated model estimates

\begin{tabular}{lllll}
\hline & Parameters estimate & Standard error & $T$ statistic & $p$ value \\
\hline$[\mathrm{AW}]->[\mathrm{SGA}]$ & 0.304 & 0.075 & 4.035 & 0.000 \\
{$[\mathrm{AW}]->[\mathrm{RD}]$} & 0.044 & 0.086 & 0.508 & 0.611 \\
{$[\mathrm{SGA}]->[\mathrm{RD}]$} & 0.145 & 0.085 & 1.696 & 0.090 \\
\hline
\end{tabular}

Table 7 Final aggregated model estimates

\begin{tabular}{lllll}
\hline & Parameters estimate & Standard error & $T$ statistic & $p$ value \\
\hline$[\mathrm{AW}]->[\mathrm{SGA}]$ & 0.304 & 0.075 & 4.035 & 0.000 \\
{$[\mathrm{SGA}]->[\mathrm{RD}]$} & 0.158 & 0.081 & 1.949 & 0.051 \\
\hline
\end{tabular}

Model fit: ${ }^{2}(1)=0.258, p=0.612 ; \mathrm{CFI}=1 ; \mathrm{GFI}=0.999 ; \mathrm{NFI}=0.986 ; \mathrm{RMR}=0.016$ 
Table 8 Moderation analysis (industry): model estimates for manufacturing and construction

\begin{tabular}{lllrr}
\hline & Parameters estimate & Standard error & $T$ statistic & $p$ value \\
\hline$[\mathrm{L}]->[\mathrm{SC}]$ & 0.762 & 0.063 & 12.036 & 0.000 \\
{$[\mathrm{~L}]->[\mathrm{E}]$} & 0.760 & 0.064 & 11.907 & 0.000 \\
{$[\mathrm{~L}]->[\mathrm{R}]$} & 0.723 & 0.072 & 10.049 & 0.000 \\
{$[\mathrm{~L}]->[\mathrm{P}]$} & 0.329 & 0.099 & 3.320 & 0.001 \\
{$[\mathrm{~L}]->[\mathrm{M}]$} & -0.250 & 0.141 & -1.778 & 0.075 \\
{$[\mathrm{SC}]->[\mathrm{P}]$} & 0.262 & 0.072 & 3.664 & 0.000 \\
{$[\mathrm{E}]->[\mathrm{P}]$} & 0.409 & 0.072 & 5.709 & 0.000 \\
{$[\mathrm{R}]->[\mathrm{P}]$} & 0.082 & 0.066 & 1.251 & 0.211 \\
{$[\mathrm{P}]->[\mathrm{M}]$} & 1.131 & 0.123 & 9.175 & 0.000 \\
{$[\mathrm{M}]>[\mathrm{SGA}]$} & 0.253 & 0.141 & 1.791 & 0.073 \\
{$[\mathrm{SGA}]->[\mathrm{RD}]$} & 0.143 & 0.148 & 0.970 & 0.332 \\
\hline
\end{tabular}

Table 9 Moderation analysis (industry): model estimates for trade and financial services
Model fit: ${ }^{2}(17)=68.16$, $p<0.001 ; \mathrm{CFI}=0.895$, $\mathrm{GFI}=0.779 ; \mathrm{NFI}=0.868$; $\mathrm{RMR}=0.089$

Table 10 Moderation analysis (industry): model estimates for other services

Model fit: ${ }^{2}(17)=104.507$, $p<0.001$; CFI $=0.802$,

$\mathrm{GFI}=0.682 ; \mathrm{NFI}=0.777$;

$\mathrm{RMR}=0.116$

\begin{tabular}{lclcc}
\hline & Parameters estimate & Standard error & $T$ statistic & $P$ value \\
\hline$[\mathrm{L}]->[\mathrm{SC}]$ & 0.842 & 0.040 & 20.867 & 0.000 \\
{$[\mathrm{~L}]->[\mathrm{E}]$} & 0.895 & 0.028 & 32.456 & 0.000 \\
{$[\mathrm{~L}]->[\mathrm{R}]$} & 0.847 & 0.039 & 21.571 & 0.000 \\
{$[\mathrm{~L}]->[\mathrm{P}]$} & 0.399 & 0.123 & 3.242 & 0.001 \\
{$[\mathrm{~L}]->[\mathrm{M}]$} & 0.499 & 0.138 & 3.624 & 0.000 \\
{$[\mathrm{SC}]->[\mathrm{P}]$} & 0.486 & 0.073 & 6.694 & 0.000 \\
{$[\mathrm{E}]->[\mathrm{P}]$} & 0.310 & 0.088 & 3.534 & 0.000 \\
{$[\mathrm{R}]->[\mathrm{P}]$} & 0.213 & 0.075 & -2.837 & 0.005 \\
{$[\mathrm{P}]->[\mathrm{M}]$} & 0.427 & 0.138 & 3.085 & 0.002 \\
{$[\mathrm{M}]>[\mathrm{SGA}]$} & 0.465 & 0.109 & 4.273 & 0.000 \\
{$[\mathrm{SGA}]->[\mathrm{RD}]$} & 0.227 & 0.132 & 1.727 & 0.084 \\
\hline
\end{tabular}

\begin{tabular}{lllll}
\hline & Parameters estimate & Standard error & $T$ statistic & $p$ value \\
\hline$[\mathrm{L}]->[\mathrm{SC}]$ & 0.829 & 0.046 & 18.186 & 0.000 \\
{$[\mathrm{~L}]->[\mathrm{E}]$} & 0.770 & 0.059 & 12.942 & 0.000 \\
{$[\mathrm{~L}]->[\mathrm{R}]$} & 0.799 & 0.053 & 15.173 & 0.000 \\
{$[\mathrm{~L}]->[\mathrm{P}]$} & 0.194 & 0.122 & 1.585 & 0.113 \\
{$[\mathrm{~L}]->[\mathrm{M}]$} & 0.305 & 0.104 & 2.938 & 0.003 \\
{$[\mathrm{SC}]->[\mathrm{P}]$} & 0.504 & 0.086 & 5.879 & 0.000 \\
{$[\mathrm{E}]->[\mathrm{P}]$} & 0.118 & 0.076 & 1.549 & 0.121 \\
{$[\mathrm{R}]->[\mathrm{P}]$} & 0.230 & 0.081 & 2.832 & 0.005 \\
{$[\mathrm{P}]->[\mathrm{M}]$} & 0.664 & 0.100 & 6.656 & 0.000 \\
{$[\mathrm{M}]>[\mathrm{SGA}]$} & 0.301 & 0.133 & 2.267 & 0.023 \\
{$[\mathrm{SGA}]->[\mathrm{RD}]$} & 0.073 & 0.145 & 0.502 & 0.615 \\
\hline
\end{tabular}

\section{Discussion}

We investigated strategy execution in the context of the interdependency between the main constructs and their impact on strategy execution results. We have confirmed the relations between employees and their impact on execution processes, which are crucial for accomplishing the tasks designed to achieve strategic 
goals, as confirmed by Becker and Huselid (2006) and further extended by Greer et al. (2017). Furthermore, our results are coherent with Hitt et al.'s (2001) conclusion that human capital, as a separate resource, moderates the relationship between a company's strategy and performance results. We have also revealed the significant impact of leadership on other constructs (strategy content, employees and resources), which further influences the strategic goals achievement. This finding is in line with the results of Collier et al. (2004), who demonstrated that employee involvement increases the efficiency of execution processes. Our result contradicts the conclusions of Alamsjah (2011), who reported that involvement of CEO leadership during execution does not have a significant impact on its result; however, Alamsjah's study measured the perception of managers, whereas our study measured the statistical data on a company's performance. Our mediation analysis did not confirm the predicted relationship between strategy and measures. As proposed by Thorpe and Morgan (2007), the clarity of strategy concept and strategic goals should result in better coordination and reporting of the final outcome of execution activities. However, in our study, that relation was not significant. The relationship between processes and strategic goals achievement, which was discussed by Higgins (2005), presented a similar contradictory result. To explain this lack of a relationship, we tried to understand whether there are factors that may affect the interdependency.

We conducted the moderated mediation analysis, therefore, in order to investigate the influence of size and industry on our constructs. Our results do not reveal an impact in the case of size of the company, which contradicts Loan-Clarke et al. (2000) claimed that in SMEs there are more areas to which managers are forced to pay attention in order to execute the strategy successfully. Our findings do indicate a slight influence in the case of industry, although our results are not as significant as those presented by GarridoVega et al. (2014). Hence, the reported results are not coherent, and it is worth noting that some studies have found that different industries do not differ in terms of factors influencing the strategy execution process (Rho et al. 2001). Therefore, more complex and representative investigation is recommended.

\section{Conclusions and limitations}

As indicated by Miller et al. (2008), half or more of strategic initiatives are not successful because of factors that are under executive control. This is why we have focused on internal factors and tried to explain their interdependency. We created an initial model in order to investigate the direct and indirect relationships between our variables. Based on the initial results, we further modified the model, but this still did not reveal the perfect fit indexes; therefore, we introduced the aggregated model. As our constructs are reliable but not divergently valid despite conceptual heterogeneity, we proposed an aggregated model without detailed factors, and the model analysis confirmed that it fits the data. Based on our research results, we can conclude that the relationships identified in the model were not moderated by the size of the company, although the initial model could be specific for different industries. In the case of the aggregated model, industry and size are not relevant.

The main contribution of our study, therefore, is that the strategy execution process should be perceived as a set of integrated factors that should be analysed from an aggregated perspective. Such an approach was first introduced by Zeps and Ribickis (2015), and we have further developed this concept. Integrating all these factors requires a holistic and systematic approach and the development of an effective system of communication (Shimizu 2017). Our proposed model offers a conceptual framework that could be further developed to examine the process of strategy execution over time. We recommend that attention is paid to ensuring the effectiveness of all the constructs aggregated in one process, instead of focusing only on the efficiency of final results; accordingly, it is necessary to consider the execution process as an execution-as-learning concept (Lee and Puranam 2016). This is important because, as our study reveals, the awareness of strategy execution barriers (defined as comprehensive barrier perception) impacts the strategic goals achievement and not the revenue dynamics directly. This finding is also in line with by Hrebiniak's (2013) argument that strategy execution is not a set of individual decisions but a series of interdependent actions. Future research could also include the perspective of micro-foundations to integrate the holistic view with the individuals' 
identity and preferences that influence the context of interdependency.

The main limitation of our study was the type of data collected (opinion about the item investigated). This enabled us to study the perceptions of respondents while expressing their opinion about the impact of a particular factor. However, as these latent variables were not directly measured and the constructs were based on a subjective perspective, there were no objective data that could be used instead. This limitation was decreased in the case of measurement of performance, which included strategic goals achievement that was based both on the personal perceptions and opinions of CEOs and on objective financial data (revenue dynamics).

Acknowledgements The project is financed by the Ministry of Science and Higher Education in Poland under the programme "Regional Initiative of Excellence" 2019-2022 project number 015/RID/2018/19 total funding amount 10721 040,00 PLN. Project No. 2014/13/D/HS4/01425 was financed by the National Science Centre.

Open Access This article is licensed under a Creative Commons Attribution 4.0 International License, which permits use, sharing, adaptation, distribution and reproduction in any medium or format, as long as you give appropriate credit to the original author(s) and the source, provide a link to the Creative Commons licence, and indicate if changes were made. The images or other third party material in this article are included in the article's Creative Commons licence, unless indicated otherwise in a credit line to the material. If material is not included in the article's Creative Commons licence and your intended use is not permitted by statutory regulation or exceeds the permitted use, you will need to obtain permission directly from the copyright holder. To view a copy of this licence, visit http://creativecommons.org/licenses/by/4.0/.

\section{Appendix}

\begin{tabular}{|c|c|}
\hline Construct & Items \\
\hline \multirow[t]{5}{*}{ Leadership } & $\begin{array}{l}\text { Managers do not identify themselves with } \\
\text { company's strategic goals }\end{array}$ \\
\hline & $\begin{array}{l}\text { Managers do not provide information about the } \\
\text { strategy and the process of its execution to } \\
\text { other employees }\end{array}$ \\
\hline & $\begin{array}{l}\text { Managers are not engaged in relations with } \\
\text { company's stakeholders (employees, clients, } \\
\text { suppliers, institutions, etc.) }\end{array}$ \\
\hline & Managers do not execute the tasks assigned \\
\hline & $\begin{array}{l}\text { Managers have a low tendency to modify the } \\
\text { strategy developed }\end{array}$ \\
\hline
\end{tabular}

\begin{tabular}{|c|c|}
\hline Construct & Items \\
\hline \multirow[t]{5}{*}{$\begin{array}{l}\text { Strategy } \\
\text { content }\end{array}$} & $\begin{array}{l}\text { Strategy did not include the influence of } \\
\text { external factors (changes in the industry, } \\
\text { competitive situation, stakeholders' } \\
\text { expectations) }\end{array}$ \\
\hline & $\begin{array}{l}\text { Strategy did not include the strengths and } \\
\text { weaknesses of the organization (mainly the } \\
\text { performance results and development } \\
\text { potential) }\end{array}$ \\
\hline & $\begin{array}{l}\text { Strategy is not precise enough (it does not } \\
\text { clearly describe development directions and } \\
\text { strategic goals) }\end{array}$ \\
\hline & Strategy is excessively formalized or inflexible \\
\hline & $\begin{array}{l}\text { Strategy is difficult to measure and transpose for } \\
\text { tactical and operational goals }\end{array}$ \\
\hline \multirow[t]{5}{*}{ Employees } & $\begin{array}{l}\text { Employees do not have knowledge about the } \\
\text { strategy (vision/mission/strategic goals) and } \\
\text { the process of its execution }\end{array}$ \\
\hline & $\begin{array}{l}\text { Employees do not understand the relationship } \\
\text { between the strategy and their everyday } \\
\text { activities }\end{array}$ \\
\hline & $\begin{array}{l}\text { Employees are not included in the strategy } \\
\text { execution process (by having decision-making } \\
\text { power and active participation) }\end{array}$ \\
\hline & $\begin{array}{l}\text { Employees are not motivated to implement the } \\
\text { strategy }\end{array}$ \\
\hline & $\begin{array}{l}\text { Employees do not have sufficient knowledge } \\
\text { and competences to implement the strategy } \\
\text { effectively }\end{array}$ \\
\hline \multirow[t]{5}{*}{ Resources } & $\begin{array}{l}\text { The organization has too small resource } \\
\text { potential (human resources, materials, } \\
\text { technology) to execute the strategic plans }\end{array}$ \\
\hline & $\begin{array}{l}\text { The organization has too small financial } \\
\text { potential to execute the strategic plans }\end{array}$ \\
\hline & $\begin{array}{l}\text { The resources are hardly flexible and difficult to } \\
\text { modify }\end{array}$ \\
\hline & $\begin{array}{l}\text { There are difficulties with obtaining the } \\
\text { information and knowledge about the } \\
\text { resources necessary to implement the strategy }\end{array}$ \\
\hline & $\begin{array}{l}\text { There are difficulties with increasing the } \\
\text { available resource potential according to } \\
\text { strategic intentions }\end{array}$ \\
\hline \multirow[t]{5}{*}{ Processes } & $\begin{array}{l}\text { The strategy communication process is } \\
\text { ineffective }\end{array}$ \\
\hline & $\begin{array}{l}\text { The motivating process does not consider the } \\
\text { effects of strategy execution }\end{array}$ \\
\hline & The task delegating process is ineffective \\
\hline & $\begin{array}{l}\text { The process of controlling the level of strategy } \\
\text { execution and identifying the deviations is } \\
\text { ineffective }\end{array}$ \\
\hline & $\begin{array}{l}\text { The process of reaction to observed deviations } \\
\text { (making necessary corrections and } \\
\text { modifications) is ineffective }\end{array}$ \\
\hline
\end{tabular}




\begin{tabular}{ll}
\hline Construct & Items \\
\hline Measures & A set of specific financial and non-financial \\
measures used to strategy execution \\
measurement has not been created \\
The measures of strategy execution process do \\
not reflect all strategic goals \\
Measures of strategy execution process are not \\
related to other measures of company's \\
performance \\
There is no regular strategy execution \\
measurement process \\
The system of measures is not modified during \\
the strategy execution (if necessary)
\end{tabular}

\section{References}

(9) (PDF) Walidacja narzędzia pomiarowego w naukach o zarządzaniu. https://www.researchgate.net/publication/ 333292771_Walidacja_narzedzia_pomiarowego_w_ naukach_o_zarzadzaniu. Accessed 18 Dec 2019

Aksakal E, Dagdeviren M (2014) Analysing reward management framework with multi-criteria decision-making methods. Procedia Soc Behav Sci 147:147-152

Alamsjah F (2011) Key success factors in implementing strategy: middle-level managers' perspectives. Procedia Soc Behav Sci 24:1444-1450

Alashloo F, Castka P, Sharp J (2005) Towards understanding the impeders of strategy execution in higher education: a case study of $\mathrm{HE}$ institutes in Iran. Qual Assur Educ 13(2):132-147

Al-Khouri A (2014) Strategy and execution: lessons learned from the public sector. Int Bus Res 7(10):61-73

Alpha A, Sabourin V (2012) Management practices: an analysis of gender differences in the strategy execution. Afr J Bus Manag 6(7):2467-2483

Anand S, Merrifield D (1982) Strategic resource allocation procedures. In: Lorange $\mathrm{P}$ (ed) Execution of strategic planning. Prentice Hall, Englewood Cliffs, pp 68-83

Angel R (2008) Linking execution with strategy in support functions. Ivey Bus J 72(2):1-2

Ariyachandra T, Frolick M (2008) Critical success factors in business performance management: striving for success. Inf Syst Manag 25(2):113-120

Bakar L, Ahmad H (2010) Assessing the relationship between firm resources and product innovation performance. Bus Process Manag J 16(3):420-435

Balarezo J, Nielsen B (2017) Scenario planning as organizational intervention: an integrative framework and future research directions. Rev Int Bus Strategy 27(1):2-52

Bandara W, Gable G, Rosemann M (2005) Factors and measures of business process modelling: model building through a multiple case study. Eur J Inf Syst 14(4):347-360
Barnett W, Carroll G (1995) Modeling internal organizational change. Ann Rev Sociol 21:217-236

Becker B, Huselid M (2006) Strategic human resource management: where do we go from here? J Manag 32:898-925

Beer M, Eisenstat R (2000) The silent killers of strategy execution and learning. Sloan Manag Rev 41:29-40

Beer M, Nohria N (2000) Cracking the code of change. Harv Bus Rev 78(3):133-141

Bell P, Dean G, Gottschalk P (2010) Information management in law enforcement: the case of police intelligence strategy execution. Int J Inf Manag 30(4):343-349

Bolboli S, Reiche M (2013) A model for sustainable business excellence: execution and the roadmap. TQM J 25(4):331-346

Boonstra A (2006) Interpreting an ERP-execution project from a stakeholder perspective. Int J Project Manag 24(1):38-52

Borsboom D, Mellenbergh G, van Heerden J (2003) The theoretical status of latent variables. Psychol Rev 110(2):203-219

Bossidy L, Charan R (2011) Execution. The discipline of getting things done. Random House, London

Bower J (1986) Managing the resource allocation process: a study of corporate planning and investment. Harvard Business School Press, Boston

Brenes E, Mena M, Molina G (2008) Key success factors for strategy execution in Latin America. $J$ Bus Res 61(6):590-598

Burgelman R (1983) A process model of internal corporate venturing in a major diversified firm. Adm Sci Q 28(2):223-244

Cândido C, Santos S (2015) Strategy execution: what is the failure rate? J Manag Organ 21(2):237-262

Carpenter M, Westphal J (2010) The strategic context of external network ties: examining the impact of directors appointments on board involvement in strategic decision making. Acad Manag J 4(4):639-660

Chaola P, Pratoom K, Raksong S (2015) A conceptual model of strategic management renewal orientation and firm performance. Proc Acad Strateg Manag 14(2):18-32

Chatterjee A, Hambrick D (2007) It's all about me: narcissistic chief executive officers and their effects on company strategy and performance. Adm Sci Q 52(3):351-386

Chin M, Hambrick D, Trevino L (2013) Political ideologies of CEOs: illustrative evidence of the influence of executive values on corporate social responsibility. Adm Sci Q 58(2):197-232

Collier N, Fishwick F, Floyd S (2004) Managerial involvement and perceptions of strategy process. Long Range Plan 37:67-83

Conrad C (1990) Strategic organizational communication, holt. Rinehart \& Winston, Fort Worth

Diamantopoulos A, Siguaw J (2006) Formative versus reflective indicators in organizational measure development: a comparison and empirical illustration. $\mathrm{Br} \mathrm{J}$ Manag 17(4):263-282

Driedonks A, Gevers M, Weele J (2014) Success factors for sourcing teams: how to foster sourcing team effectiveness. Eur Manag J 32(2):288-304

Duarte A, Austin I (2016) I see the future associations between innovation and resources in the case of an exporting 
Western Australian regional family firm. Rev Int Bus Strategy 26(3):314-333

EFQM Excellence Model (2013) The European foundation for quality management. https://www.efqm.org/index.php/ efqm-model/

Eisenhardt KM, Martin JA (2000) Dynamic capabilities: what are they? Strateg Manag J 21:1105-1121

El-Masri M, Orozco J, Tarhini A, Tarhini T (2015) The impact of IS-business alignment practices on organizational choice of IS-Business alignment strategies. In: The 19th Pacific Asia conference on information systems (PACIS 2015), paper 215, Singapore, 6-9 July

Favaro K (2015) Defining strategy, implementation, and execution. Retrieved from Harvard Business Review. https:// hbr.org/2015/03/defining-strategy-implementation-andexecution

Forbes D, Milliken F (1999) Cognition and corporate governance understanding boards of directors as strategic decision-making groups. Acad Manag Rev 24(3):489-505

Foreman J, Argenti PA (2005) How corporate communication influences strategy execution, reputation and the corporate brand: an exploratory qualitative study. Corp Reput Rev 8(3):245-264

Galbraith J, Kazanjian R (1986) Strategy execution: structure systems and process, 2nd edn. West Publishing, New York

Garrido-Vega P, Ortega Jimenez C, Pĕrez de los Rios J, Morita M (2014) Execution of technology and production strategy practices: relationship levels in different industries. Int $\mathbf{J}$ Prod Econ 161:201-216

Garvin D (2013) Where execution breaks down: why can't companies get the job done? Conf Board Rev 3:38-45

Getz G, Lee J (2011) Why your strategy isn't working. Bus Strategy Ser 12(6):303-305

Gorzeń-Mitka I (2015) Risk management in small and mediumsized enterprises: a gender-sensitive approach. Probl Manag 21st Century 10(2):77-87

Greer C, Lusch R, Hitt M (2017) A service perspective for human capital resources: a critical base for strategy execution. Acad Manag Perspect 31(2):137-158

Grover V, Fiedler K, Teng J (1999) The role of organizational and information technology antecedents in reengineering initiation behavior. Decis Sci 30(3):749-781

Guetzkow H (1965) Communication in organizations. In: March J (ed) Handbook of organizations. Rand-McNally, Chicago, pp 534-572

Håkonsson D, Burton R, Obel B, Lauridsen J (2012) Strategy execution requires the right executive style: evidence from Danish SMEs. Long Range Plan 45(2-3):182-208

Hambrick DC (1981) Strategic awareness within top management teams. Strateg Manag J 2:263-279

Hamdi N, Goethert R (1985) Execution: theories, strategies and practice. Habitat Int 9(1):33-44

Hammer M, Stanton S (1995) The reengineering revolution. Harper Collins, New York

Hanafizadeh P, Moayer S (2008) A methodology to define strategic processes in organizations: an exploration study in managerial holding companies. Bus Process Manag J 14(2):219-227

Hanley C (2007) The execution challenge: translating strategy into action. Bank Account Finance 20(6):17-20
Hardesty DM, Bearden WO (2004) The use of expert judges in scale development: implications for improving face validity of measures of unobservable constructs. J Bus Res 57(2):98-107

HBR Spotlight (2010) How hierarchy can hurt strategy execution. Harv Bus Rev 88(7-8):74-75

Heide M, Grønhaug K, Johannessen S (2002) Exploring barriers to the successful execution of a formulated strategy. Scand J Manag 18(2):217-231

Herrmann P, Nadkarni S (2014) Managing strategic change: the duality of CEO personality. Strateg Manag J 35(9): 1318-1342

Higgins J (2005) The eight ' $S$ ' of successful strategy execution. J Change Manag 5(1):3-13

Hitt M, Bierman L, Shimzu K, Kochhar R (2001) Direct and moderating effects of human capital on strategy and performance in professional service firms: a resourced-based perspective. Acad Manag J 44:13-28

Ho J, Wu A, Wu S (2013) Performance measures, consensus on strategy execution and performance: evidence from the operational-level of organizations. Acc Organ Soc 39(1):3-4

Hrebiniak L (2005) Making strategy work: leading effective execution and change. Wharton School Publishing, New Jersey

Hrebiniak L (2013) Making strategy work: leading effective execution and change. Pearson Education, New Jersey

Huselid A, Becker E (2011) Bridging micro and macro domains: workforce differentiation and strategic human resource management. J Manag 37(2):421-428

Huy Q (2011) How middle managers' group-focus emotions and social identities influence strategy execution. Strateg Manag J 32:1387-1410

Ittner C, Larcker D (2003) Coming up short on non-financial performance measurement. Harv Bus Rev 81(11):88-95

Jiang N, Carpenter V (2013) A case study of issues of strategy execution in internationalization of higher education. Int $\mathbf{J}$ Educ Manag 27(1):4-18

Kaplan RS, Norton DP (2001) The strategy-focused organization: how balanced scorecard companies thrive in the new business environment, 1st edn. Soundview Executive Book Summaries. Harvard Business School Press, Concordville, pp 148-159

Kazmi A (2008) A proposed framework for strategy execution in the Indian context. Manag Decis 46(10):1564-1581

Khadem R (2008) Alignment and follow-up: steps to strategy execution. J Bus Strategy 29(6):29-32

Kipp M, Kipp M (2012) Strategy and the board: pivotal dialog in governance. In: Sterling J, Rader D (eds) Conference report. Dynamic discourse drives effective strategy execution: association for strategic planning's annual conference recap, strategy and leadership, vol 40, no 6, pp 5-6

Kohlbacher M (2010) The effects of process orientation: a literature review. Bus Process Manag J 16(1):135-152

Law C, Ngai E (2007) ERP systems adoption: an exploratory study of the organizational factors and impacts of ERP success. Inf Manag 44(4):418-432

Lee E, Puranam P (2016) The execution imperative: why one should implement even imperfect strategies perfectly. Strateg Manag J 37(8):1529-1546 
Legge R (2014) The leader's role in implementing strategy. Cent N Y Bus J. https://www.cnybj.com/the-leaders-rolein-implementing-strategy/. Access 10 July 2019

Lepsinger R (2006) Surveying the gap: nearly half of all leaders see a disconnect between strategy and execution. Bus Credit 108(9):56-57

Lingle J, Schiemann W (1994) Is data scatter subverting your strategy? Manag Rev 83(5):53-56

Loan-Clarke J, Smith A, Whittaker J (2000) Competence-based management development in small and medium-sized enterprises: a multi-stakeholder analysis. Int J Train Dev 4(3):176-195

Maditinos D, Chatzoudes D, Sarigiannidis L (2014) Factors affecting e-business successful execution. Int J Commer Manag 24(4):300-320

Malmi T (2001) Balanced scorecard in Finnish companies: a research note. Manag Account Res 12(2):207-220

Mankins M, Steele R (2005) Turning great strategy into great performance. Harv Bus Rev 83(7):64-72

Markiewicz P (2012) Methodical aspects of applying strategy map in an organization. Bus Manag Educ 11(1):153-167

Martin R (2010) Drawing a line between strategy and execution almost guarantees failure. Harv Bus Rev 88(7-8):64-71

Martin-Castilla J, Rodriguez-Ruiz O (2008) EFQM model: knowledge governance and competitive advantage. J Intellect Cap 9(1):133-156

McNulty T, Pettigrew A (1999) Strategist on the board. Organ Stud 20:47-74

Mezger S, Violani M (2011) Seven basic strategic missteps and how to avoid them. Strategy Leadersh 39(6):19-26

Miller S (1997) Implementing strategic decisions: four key success factors. Organ Stud 18(4):577-602

Miller S, Wilson D, Hickson D (2004) Beyond planning strategies for successfully implementing strategic decisions. Long Range Plan 37:201-218

Miller S, Hickson D, Wilson D (2008) From strategy to action: involvement and influence in top level decisions. Long Range Plan 41(6):606-628

Mintzberg H (2002) The strategy process, 4th edn. Prentice Hall, New York

Morgan N, Kaleka A, Katsikeas C (2004) Antecedents of export venture performance: a theoretical model and empirical assessment. J Market 68(1):90-108

Nag R, Hambrick D, Chen M (2007) What is strategic management, really? Inductive derivation of a consensus definition of the field. Strateg Manag J 28(9):935-955

O'Reilly C, Caldwell D, Chatman J, Lapiz M, Self W (2010) How leadership matters: the effects of leaders' alignment on strategy execution. Leadersh Q 21:104-113

Obeidat B, Al-Hadidi A, Tarhini A, Masa'deh R (2017) Factors affecting strategy execution: a case study of pharmaceutical companies in the Middle East. Rev Int Bus Strategy 27(3):386-408

Okumus F (2003) A framework to implement strategies in organizations. Manag Decis 41(9):871-882

Olsen M, Tse E, West J (1992) Strategic management in the hospital industry. Van Nostrand Reinhold, New York

Olson E, Slater S, Hult G (2005) The importance of structure and process to strategy execution. Bus Horiz 48(1):47-54
Paillé P, Chen Y, Boiral O, Jin J (2014) The impact of human resource management on environmental performance: an employee-level study. J Bus Ethics 121(3):451-466

Peterson S, Walumbwa F, Byron K, Myrowitz J (2009) CEO positive psychological traits, transformational leadership, and form performance in high-technology start-up and established firms. J Manag 35(2):348-368

Philipsen RLC, Kemp RGM (2003) Capabilities for growth: an exploratory study on medium-sized firms in the Dutch ICT services and life sciences, vol 137. EIM, Zoetermeer

Pleshko L, Nickerson I (2008) Strategic orientation, organizational structure, and the associated effects on performance in industrial firms. Acad Strateg Manag J 7:95-111

Postma T, Zwart P (2001) Strategic research and performance of SMEs. J Small Bus Strategy 12:52-64

Prahalad C, Bettis R (1987) The dominant logic: a new linkage between diversity and performance. Strateg Manag J 7:485-501

Pugliese A, Bezemer P, Zattoni A, Huse M, Van Den Bosch F, Volberda H (2009) Boards of directors' contribution to strategy: a literature review and research agenda. Corp Gov Int Rev 17:292-306

Radomska J (2016) Tools and actions for increasing the effectiveness of the strategy execution. In: Bilgin M, Danis H, Demir E, Can U (eds) Business challenges in the changing economic landscape, vol 2, proceedings of the 14th Eurasia business and economics society conference. Springer, pp 23-32

Rajasekar J (2014) Factors affecting effective strategy execution in a service industry: a study of electricity distribution companies in the Sultanate of Oman. Int J Bus Soc Sci 5(9):169-183

Ranganathan C, Dhaliwal J (2001) A survey of business process reengineering practices in Singapore. Inf Manag 39(2):125-134

Raps A (2005) Strategy execution: an insurmountable obstacle? Handb Bus Strategy 6(1):141-146

Reed R, Buckley M (1988) Strategy in action: techniques for implementing strategy. Long Range Plan 21(3):67-74

Renckly G (2004) Human resources. Barron's Educational Series, New York

Resick C, Whitman D, Weingarden S, Hiller N (2009) The bright-side and the dark-side of CEO personality: examining core self-evaluation, narcissism, transformational leadership, and strategic influence. J Appl Psychol 94(6): 1365-1381

Rho B, Park K, Yu Y (2001) An international comparison of the effect of manufacturing strategy-execution gap on business performance. Int J Prod Econ 70:89-97

Robbin S, DeCenzo D (2005) Fundamentals of management: essential concepts and applications. Prentice Hall, Upper Saddle River

Saif N, Razzaq N, Rehman U, Javed A (2013) The concept of change management in today's business world. Inf Knowl Manag 2(6):28-33

Salas K, Huxley C (2014) Enhancing visualization to communicate and execute strategy. J Strategy Manag 7(2):109-126

Serra C, Kunc M (2015) Benefits realisation management and its influence on project success and on the execution of business strategies. Int J Proj Manag 33:53-66 
Shah M, Sid Nair C (2014) Turning the ship around: rethinking strategy development and execution in universities. Qual Assur Educ 22(2):145-157

Shimizu K (2017) Senders' bias: how can top managers' communication improve or not improve strategy execution? Int J Bus Commun 54(1):52-69

Siam M, Hilman H (2014) Relationship of strategy execution plan dimensions on organization performance of higher educational institution in Palestine. Asian Soc Sci 10(13):131-133

Sikdar A, Payyazhi J (2014) A process model of managing organizational change during business process redesign. Bus Process Manag J 20(6):971-998

Sirkin H, Keenan P, Jackson A (2005) The hard side of change management. Harv Bus Rev 83(10):109-118

Sørensen O, Holman D (2014) A participative intervention to improve employee well-being in knowledge work jobs: a mixed-methods evaluation study. Work Stress Int J Work Health Organ 28(1):67-86

Stadler C, Hinterhuber H (2005) Shell, Siemens and DaimlerChrysler: leading change in companies with strong values. Long Range Plan 38:467-484

Sterling J (2003) Translating strategy into effective execution: dispelling the myths and highlighting what works. Strategy Leadersh 31(3):27-34

Suddaby R (2010) Editor's comments: construct clarity in theories of management and organization. Acad Manag Rev 35(3):346-357

Sue A, Khawaja S (2015) User perceptions towards an ERP system: comparing the post-execution phase to the preexecution phase. J Enterp Inf Manag 28(2):243-259

Sull D, Homkes R, Sull C (2015) Why strategy execution unravels: and what to do about it. Harv Bus Rev 93(3):58-66

Tabachnick B, Fidell L (2001) Using multivariate analysis. Allyn and Bacon, Boston

Terziovski M, Fitzpatrick P, O’Neill P (2003) Successful predictors of business process reengineering (BPR) in financial services. Int J Prod Econ 84(1):35-50
Thanyawatpornkul R, Siengthai S, Johri L (2016) Employee's perspective towards strategy execution in facility management in Thailand. Facilities 34(11/12):682-702

Thorpe E, Morgan R (2007) In pursuit of the ideal approach to successful marketing strategy execution. Eur J Mark 41:659-677

Vermuelen F, Phanish P, Ranjay G (2010) Change for change's sake. Harv Bus Rev 88(6):71-76

Wart V (2010) Increasing organizational investment in employee development. In: Condrey E (ed) Handbook of human resource management in government. Wiley, San Francisco

Waterman R, Peters T, Phillips J (1980) Structure is not organization. Bus Horiz 23(3):14-26

Willcocks L, Currie W, Jackson S (1997) In pursuit of the reengineering agenda in public administration. Public Adm 75(4):617-649

Wongrassamee S, Simmons J, Gardiner P (2003) Performance measurement tools: the Balanced Scorecard and the EFQM excellence model. Meas Bus Excell 7(1):14-29

Wooldridge B, Floyd S (1990) The strategy process, middle management involvement, and organizational performance. Strateg Manag J 11:231-241

Yaprak A, Xu S, Cavusgil E (2011) Effective global strategy execution. Manag Int Rev 51(2):179-192

Zeps A, Ribickis L (2015) Strategy development and execution-process and factors influencing the results: case study of Latvian organizations. Procedia Soc Behav Sci 213:931-937

Zhang Y, Rajagopalan N (2010) Once an outsider, always an outsider? CEO origin, strategic change, and firm performance. Strateg Manag J 31(3):334-346

Publisher's Note Springer Nature remains neutral with regard to jurisdictional claims in published maps and institutional affiliations. 